Marcin RACHWAE

Uniwersytet im. Adama Mickiewicza, Poznań

\title{
Współczesna demokracja a społeczeństwo obywatelskie na przykładzie Polski
}

$\mathrm{W}$

spółczesna demokracja dla prawidłowego funkcjonowania potrzebuje społeczeństwa obywatelskiego, a zatem społeczeństwa upodmiotowionych, świadomych jednostek, które podejmują aktywność w sferze społecznej. Brak tego komponentu powoduje wiele problemów, jak chociażby niską frekwencję w procedurach wyborczych i referendalnych, co osłabia legitymację władzy i kłopoty przede wszystkim z wdrażaniem decyzji politycznych.

Wielu autorów podkreśla, iż w latach 80. XX wieku w Polsce mieliśmy do czynienia z bardzo intensywnym rozwojem społeczeństwa obywatelskiego, co wpłynęło na to, iż wówczas rządzący zgodzili się na rozmowy z demokratyczną opozycją. W efekcie rozmów Okragłego Stołu, wyborów czerwcowych 1989 roku i późniejszych wydarzeń doszło do instytucjonalizacji demokratycznego reżimu politycznego. Po upływie kilku lat transformacji systemowej coraz głośniej podnoszono w dyskursie publicznym kwestię słabości polskiego społeczeństwa obywatelskiego. W związku z tym można zadać pytanie, co się stało ze społeczeństwem polskim? Społeczeństwo, które potrafiło zmusić niedemokratyczną władzę do ustępstw po zmianie 1989 roku coraz słabiej angażuje się w życie publiczne. Próba odniesienia się do tak zarysowanego problemu była celem niniejszego szkicu.

Pojęcie społeczeństwa obywatelskiego należy obecnie do podstawowych terminów refleksji i praktyki politycznej, aczkolwiek nie stanowi odkrycia ostatnich dziesięcioleci. Historia idei sięga starożytnej Grecji i Rzymu. Przedmiotowe pojęcie, rozwijane zwłaszcza w okresie Oświecenia we Francji i Szkocji, znalazło się także w centrum uwagi takich myślicieli jak Hegel i Marks. Następnie, mimo iż pojawiało się u różnych autorów w XIX i XX wieku, pozostawało jakby na uboczu głównego nurtu rozwoju idei politycznych i społecznych.

Wielki powrót idei społeczeństwa obywatelskiego rozpoczął się wraz z rozwojem ruchów dysydenckich w państwach bloku sowieckiego w la- 
tach siedemdziesiątych i osiemdziesiątych XX wieku. Równocześnie z pojawieniem się tej idei w państwach komunistycznych i socjalistycznych rozpoczął się renesans zainteresowania tą tematyką w świecie demokratycznym ${ }^{1}$. Jak podkreśliła W. Paradowska: „Trafne wydają się opinie badaczy tej problematyki, że o ile na Wschodzie idea społeczeństwa obywatelskiego służyła walce ideologicznej z dyktaturą państwa, o tyle na Zachodzie idea ta pobudzała do pracy teoretycznej"2.

George Weigel w pracy Ostateczna rewolucja wyraził pogląd, iż nie byłoby upadku komunizmu, niezależnie od sprzyjających okoliczności międzynarodowych, bez moralnego zaangażowania samych obywateli, bez „zwrócenia się ku dobru, ku temu, co prawdziwe i ludzkie i czynnego sprzeciwu wobec kultury kłamstwa"3. Autor Ostatecznej rewolucji wskazał zarazem na kluczowy czynnik przyspieszający to dzieło - punkt zwrotny owej rewolucji sumienia - pamiętne słowa Jana Pawła II do rodaków wygłoszone podczas pierwszej pielgrzymki w 1979 roku, które brzmiały: „Niech zstąpi Duch Twój i odnowi oblicze ziemi - tej ziemi”.

Należy zaznaczyć, iż niemal do końca XVIII wieku termin „społeczeństwo obywatelskie” był równoznaczny z terminami „państwo” lub „społeczeństwo polityczne”4. Widać w tym wyraźnie jego klasyczne pochodzenie. Był on bardziej lub mniej bezpośrednim tłumaczeniem cycerońskiego terminu societas civilis i arystotelesowskiego koinonia politike. W obu teoriach społeczeństwo obywatelskie lub społeczeństwo polityczne reprezentowało najwyższy etap rozwoju moralnego społeczeństwa, państwo natomiast było produktem naturalnego instynktu społecznego ludzi ${ }^{5}$.

1 J. Szacki, Liberalizm po komunizmie, Kraków 1994, s. 113 i n.; Ch. Taylor, Kiedy mówimy: społeczeństwo obywatelskie, w: Europa i społeczeństwo obywatelskie. Rozmowy w Castel Gandolfo, przygotował i przedmową opatrzył K. Michalski, Kraków 1994, s. 54-56.

2 W. Paradowska, O podmiocie etycznym i podmiocie etyki, w: Unia Europejska a społeczeństwo obywatelskie, red. R. Paradowski, Poznań 2005, s. 55.

3 Zob. szerzej: G. Weigel, Ostateczna rewolucja: Kościół sprzeciwu a upadek komunizmu, Poznań 1995, s. 12 i n.

${ }^{4}$ K. Kumar, Społeczeństwo obywatelskie: rozważania na temat użyteczności historycznego terminu, w: Ani ksiażę, Ani kupiec: Obywatel. Idea społeczeństwa obywatelskiego w myśli współczesnej, wybór i wstęp J. Szacki, Kraków 1997, s. 295.

5 Zob. szerzej: K. Dziubka, Społeczeństwo obywatelskie: wybrane aspekty ewolucji pojęcia, w: Studia z teorii polityki, t. II, red. A. W. Jabłoński, L. Sobkowiak, Wrocław 1998, s. 34-35. 
U zarania tradycji republikańskiej społeczeństwo obywatelskie rozumiano jako wspólnotę obywateli w dosłownym tego słowa znaczeniu. Była to koncepcja wykluczająca i elitarystyczna. Podkreślenia wymaga przede wszystkim to, że pojęcie obywatelstwa wiązało się nie tylko z przynależnością do wspólnoty, ale także zasadzało się na czynnym uczestnictwie w jej życiu politycznym, w podejmowaniu wraz z innymi decyzji dotyczących całej zbiorowości oraz odpowiedzialności za dobro wspólne. Obywatelstwo kojarzono wobec tego nie z uprawnieniami jednostek, którym odpowiadały powinności wspólnoty, lecz z obowiązkiem służby publicznej. Była to aktywność uniwersalna w tym sensie, iż dotyczyła uniwersalnego dobra całej wspólnoty, przewyższającego jakiekolwiek dobro partykularne. Obywatel był wolny tylko dzięki temu, że uczestniczył w życiu politycznym polis. Tego rodzaju wolność obywatelska nie miała nic wspólnego z nowożytnym pojęciem wolności indywidualnej, oznaczającej niezależność od przymusu i arbitralnej woli innego człowieka; w antycznej demokracji wolność do tego, by rządzić i być rządzonym, była podstawą politycznej równości obywateli, nie znających „dobrodziejstw niezależności osobistej”, które staną się udziałem członków nowożytnych społeczeństw obywatelskich ${ }^{6}$.

Tak więc idea społeczeństwa obywatelskiego wywodzi się pierwotnie z klasycznej tradycji republikańskiej, zapoczątkowanej przez Arystotelesa i kontynuowanej w Rzymie, do której ideałów sięgali także myśliciele włoskiego renesansu i wczesnonowożytnej myśli politycznej. Elementem spajającym tę tradycję jest przekonanie, że człowiek realizuje się przez uczestnictwo w życiu wspólnoty politycznej. Dlatego też w odniesieniu do tej tradycji, nieznającej rozdziału między społeczeństwem obywatelskim a państwem, bardziej uzasadnione wydaje się używanie terminu „wspólnota obywatelska”, pamiętając, że pojmowano ją zarazem jako wspólnotę polityczną. Jej podstawą była klasyczna idea obywatelstwa zakładająca, że obywatelskość człowieka realizuje się w działaniu i aktywnym uczestnictwie, które niejako wypływa z jego politycznej natury. Obywatel nie mógł więc być wyłącznie posłusznym poddanym tego, kto rządzi, lecz brał udział w rządzeniu wraz z innymi obywatelami. Takie ujęcie obywatelstwa było podstawą republikańskiego pojęcia wolności zakładającego, że tylko samorządna wspólnota jest prawdziwie wolna,

6 D. Pietrzyk-Reeves, Idea społeczeństwa obywatelskiego. Współczesna debata $i$ jej źródła, Wrocław 2004, s. 23-24. 
oraz wiążącego wolność obywateli z uczestnictwem w życiu politycznym wspólnoty i stanowieniu jej praw ${ }^{7}$.

Jedną z zasadniczych podstaw ładu politycznego republikańskiej wspólnoty obywatelskiej była zasada rządów prawa, przejęta przez tradycję nowożytną. Myśliciele republikańscy przedkładali rządy prawa ponad rządy ludzi, dostrzegając w prawie najważniejsze spoiwo wspólnoty obywatelskiej. Zasada rządów prawa była wiązana z republikańską formą rządu opierająca się na mieszanym ustroju politycznym ${ }^{8}$.

Współczesne rozumienie terminu społeczeństwo obywatelskie narodziło się pod koniec XVIII wieku. Powstające wówczas koncepcje społeczeństwa obywatelskiego związane były z kształtującą się myślą liberalną. $\mathrm{Na}$ przełomie XVIII i XIX wieku społeczeństwo obywatelskie przekształciło się $\mathrm{z}$ synonimu społeczeństwa politycznego w jego przeciwieństwo - „społeczeństwo odpolitycznione”9 . Choć więc analizowany termin sięga korzeniami początków myślenia o polityce, dopiero w czasach nowożytnych nabiera znaczenia, które bliższe jest czasom współczesnym.

W tradycji liberalnej zasadnicze staje się takie rozumienie społeczeństwa obywatelskiego, w którym państwo i społeczeństwo zostają rozdzielone; jest to podstawowy zwrot w myśleniu o społeczeństwie obywatelskim, odtąd nieutożsamianym już ze wspólnotą polityczną. Uprawnienie jednostki jest pojmowane jako pierwotne wobec wspólnoty - utożsamiane z wolnością i własnością niejako zajmuje miejsce tradycyjnie ujmowanych cnót. Nie wspólnota i jej dobro, lecz jednostka i jej uprawnienia są ontologiczną podstawą społeczeństwa obywatelskiego. Jego jedynym zwornikiem staje się skłonność jednostek do życia społecznego wynikająca z potrzeby bezpieczeństwa, a nie nakierowania na wspólny wszystkim cel, jakim w tradycji republikańskiej było dobro i szczęśliwe życie wszystkich członków pewnej całości politycznej. W rezultacie państwo, będące abstrakcyjną osobą prawną, powstaje po to, aby chronić wolność i własność jednostek. Odróżnione od niego społeczeństwo obywatelskie jest sferą

7 Ibidem, s. 17-18.

8 Ibidem, s. 54.

9 J. Wiśniewski, K. Żodź, Społeczeństwo obywatelskie a społeczeństwo Unii Europejskiej, w: Unia Europejska a społeczeństwo obywatelskie, red. R. Paradowski, Poznań 2005, s. 40-41; Zob. również: R. Koselleck, Trzy światy obywatelskie? Wprowadzenie do porównawczej semantyki społeczeństwa obywatelskiego w Niemczech, Anglii i Francji-zarys dziejów teorii, w: Europa i społeczeństwo obywatelskie. Rozmowy w Castel Gandolfo, przygotował i przedmową opatrzył K. Michalski, Kraków 1994, s. 112-122. 
niezależności i wolności, w tym przede wszystkim wolności ekonomicznej, przestrzenią usytuowaną pomiędzy jednostką a państwem, której państwo nie może naruszać ${ }^{10}$.

Historia pojęcia społeczeństwo obywatelskie zaczyna się od greckiego polis i Polityki Arystotelesa. Jednakże dopiero Deklaracja Praw Człowieka i Obywatela z 1789 roku przyznała prawo do bycia obywatelem - a zatem podmiotem społeczeństwa obywatelskiego - wszystkim ludziom, nadając tym samym społeczeństwu obywatelskiemu charakter normy ${ }^{11}$.

Autor opracowania Powrót spoleczeństwa obywatelskiego w Hiszpanii podkreślił, iż śledząc pojęcie od „klasycznych” (przedheglowskich) początków, można rozpatrywać społeczeństwo obywatelskie jako zespół społeczno-politycznych instytucji złożony z pięciu elementów ${ }^{12}$ :

1) władzy publicznej, która jest ograniczona i odpowiedzialna przed społeczeństwem;

2) rządów prawa;

3) sfery publicznej skupiającej zainteresowanych obywateli;

4) systemu rynkowego wolnego od korupcji;

5) szeregu dobrowolnych stowarzyszeń wszelkiego rodzaju.

Można przyjąć, iż dla procesów wykreowania społeczeństwa obywatelskiego, jak i skonsolidowanej demokracji, niezbędne są cztery warunki, które równocześnie mogą być wykorzystane jako mierniki stopnia ich rozwoju. Przedstawiają się one następująco ${ }^{13}$ :

1) konieczność wykreowania silnej klasy średniej, ażeby struktury społecznej nie zdominowały skrajności, a tym samym, aby struktura interesów społecznych była bardziej jednoznaczna, by odchylenia maksymalnie się równoważyły;

2) kwestia społecznego komunikowania się wewnątrz wspólnoty - możliwości komunikowania muszą istnieć między władzą a podwładnymi, między częściami zbiorowości (grupami, klasami, stanami itd.), między jednostkami. Nowe techniki komunikowania społecznego powiększają skalę społeczeństwa obywatelskiego, jak i skalę demokracji;

10 D. Pietrzyk-Reeves, Idea..., op. cit., s. 113.

11 K. Michalski, Przedmowa, w: Europa i społeczeństwo obywatelskie. Rozmowy w Castel Gandolfo, przygotował i przedmową opatrzył K. Michalski, Kraków 1994, s. 7.

12 V. M. Perez-Diaz, Powrót społeczeństwa obywatelskiego w Hiszpanii, Kraków 1996, s. 5.

13 Zob. szerzej: Z. Blok, Transformacja jako konwersja funkcji wewnatrzsystemowych na przyktadzie Polski, Poznań 2006, s. 277-278. 
3) pluralizm - należy zagwarantować wszystkim bez wyjątku szanse na uzyskanie przynajmniej pewnego stopnia podmiotowości, szanse na wyartykułowanie swoich potrzeb i interesów, na ich zinstytucjonalizowanie i na - w miarę konkurencyjne - warunki dochodzenia do nich;

4) akceptacja pewnego kwantum wspólnych wartości przez wszystkich członków wspólnoty.

Społeczeństwu obywatelskiemu można przypisać niezbywalny rejestr funkcji, które musi ono realizować w mniejszym bądź większym stopniu po to, aby istnieć. Należą do nich ${ }^{14}$ :

1) ochrona przed ingerencją państwa w sferę prywatną;

2) monitorowanie i kontrolowanie władzy politycznej - nie kontrolowana władza, a wraz z nią i państwo, ulega erozji i wynaturzeniu i stara się realizować wyłącznie własne interesy;

3) wychowywanie i edukacja obywateli - po to, aby mogli oni partycypować w polityce, realizować funkcje obywatelskie w skali kraju oraz we wspólnocie terytorialnej;

4) tworzenie instytucji bądź kanałów do artykulacji, ewentualnie agregacji wartości wspólnotowych i interesów społecznych - partie polityczne, będące reprezentantem interesów grupowych, ruchy polityczne i inne zrzeszenia reprezentujące mniejsze grupy interesów;

5) budowa społeczeństwa pluralistycznego, tolerancja dla inności, odmienności, mniejszości.

W tym miejscu należy zaznaczyć, iż poszczególni autorzy kładą nacisk na różne elementy, które ich zdaniem są konstytutywne dla społeczeństwa obywatelskiego. Dla jednych, społeczeństwo obywatelskie to struktura pośrednicząca między tym, co państwowe a tym, co prywatne. Inni pojmują je jako wspólnotę opartą na zobowiązaniu jednostek do działania na rzecz dobra wspólnego. Kolejny nurt za najistotniejszą wartość uznaje pluralizm rozumiany jako istnienie całej gamy zróżnicowanych (często konfliktowych) interesów zbiorowych, które mogą być artykułowane i dla ich realizacji można się dobrowolnie organizować ${ }^{15}$.

Najprostszą definicją, którą można spotkać w wielu opracowaniach dotyczących tego zagadnienia, jest określanie społeczeństwa obywatel-

14 Ibidem, s. 279-280.

15 Por. szerzej: J. Dzwończyk, Determinanty rozwoju społeczeństwa obywatelskiego w Polsce po 1989 roku, w: Rola wyborów w procesie ksztattowania się społeczeństwa obywatelskiego w Polsce, red. S. Drobczyński, M. Żyromski, Poznań 2004, s. 101-102. 
skiego jako obszaru ciał pośredniczących pomiędzy obywatelem a państwem. Wypełnia więc ono przestrzeń ,między systemem politycznym, w którym jednostki biorą bezpośredni udział w procesie sprawowania władzy, a obszarem szeroko rozumianej prywatności, na który składają się zachowania zmierzające do zaspokojenia indywidualnych potrzeb"16.

Ralf Dahrendorf charakteryzuje społeczeństwo obywatelskie poprzez istnienie autonomicznych (niesterowanych przez państwo ani inny ośrodek) organizacji i instytucji jako organów woli ludu. Zaliczają się do nich partie polityczne, związki zawodowe, przedsiębiorstwa przemysłowe, ruchy społeczne, wolne zawody, autonomiczne uniwersytety, niezależne kościoły, fundacje użyteczności publicznej ${ }^{17}$. Jeżeli takie autonomiczne organizacje i instytucje nie istnieją, nie istnieje społeczeństwo obywatelskie. Jednakże przywołany autor zwraca uwagę, iż operacyjnym rdzeniem społeczeństwa obywatelskiego nie są te instytucje jako takie, lecz zespół uprawnionych roszczeń, które można określić jako prawa obywatelskie. „Obywatelami sąjednostki wyposażone w określone prawa cywilne, polityczne i socjalne. Bez praw obywatelskich nie może istnieć społeczeństwo obywatelskie. Zniszczenie społeczeństwa obywatelskiego związane jest ze zniesieniem praw, a tworzenie społeczeństwa obywatelskiego mieści w sobie także wprowadzenie praw obywatelskich" ${ }^{\text {. }}$.

Podsumowując ten fragment rozważań można wskazać na pewne kategorie organicznie związane ze społeczeństwem obywatelskim, stanowiące zarazem determinanty jego powstania i wyznaczniki funkcjonowania. Należą do nich:

1) dobrowolne stowarzyszenia, organizacje pozarządowe - pozycja, funkcje i role dobrowolnych stowarzyszeń w społeczeństwie obywatelskim rozpatrywane są współcześnie w nurcie socjologicznym przez tak zwanych neotocquevillian;

2) kapitał społeczny, który jest wprost proporcjonalny do aktywności obywateli w różnego rodzaju stowarzyszeniach - składa się na niego zaufanie społeczne, sieci powiązań i normy wzajemności ${ }^{19}$;

16 A. Antoszewski, Społeczeństwo obywatelskie a proces konsolidacji demokracji, w: Studia z teorii polityki, t. III, red. A. Czajowski, L. Sobkowiak, Wrocław 2000, s. 10.

17 R. Dahrendorf, Co zagraża społeczeństwu obywatelskiemu, w: Europa i społeczeństwo obywatelskie. Rozmowy w Castel Gandolfo, przygotował i przedmową opatrzył K. Michalski, Kraków 1994, s. 236.

8 Ibidem, s. 236.

19 Podobnie jak inne formy kapitału, kapitał społeczny jest niezbędny, gdy chce się osiagnąć określone cele. Grupa osób jest w stanie osiagnnąć dużo więcej, jeżeli jej 
3) pluralizm - społeczeństwo obywatelskie współcześnie pojmowane jest również przez pryzmat społeczeństwa pluralistycznego, rozumianego jako „rozproszenie władzy”, „,fragmentaryzacja społeczeństwa”.

Idea społeczeństwa obywatelskiego ściśle łączy się z procesem ludzkiej emancypacji spod wszelkich form despotyzmu, członkowie społeczności określanych jako obywatelskie nie podlegają tyranii, są autonomicznymi, niezależnymi podmiotami życia społecznego. Jednakże ich egzystencja nie upływa wśród anarchii, gdyż społeczeństwo obywatelskie stanowi całość, rządzącą się wspólnie przyjętymi przez jej członków regułami i prawem. Należy zwrócić uwagę, że w rozwoju historycznym teorii społeczeństwa obywatelskiego większość rozważań odnosiła się do relacji społeczeństwo obywatelskie-państwo, odmiennie opisywanych i analizowanych w zależności od okoliczności historycznych oraz przyjętych założeń badawczo-normatywnych ${ }^{20}$.

Przyjęło się uważać, iż społeczeństwo obywatelskie odnosi się do porządku demokratycznego, a mówiąc ściślej - liberalno-demokratycznego. Jednakże zastosowanie tej kategorii do analizy procesów społeczno-politycznych zachodzących w Polsce (Europie Środkowo-Wschodniej) lat siedemdziesiątych i osiemdziesiątych XX wieku stawia problem społeczeństwa obywatelskiego w nowym świetle. Odnosząc się do przedmiotowego zagadnienia wielu badaczy doszło do konkluzji, iż należy skonstruować różne modele społeczeństwa obywatelskiego ${ }^{21}$.

członkowie darzą siebie nawzajem zaufaniem. Społeczeństwa, które wypracowały na przestrzeni wieków odpowiednio wysoki kapitał społecznego zaufania rozwijają się bez większych trudności, natomiast te, które kapitału społecznego się nie dopracowały pozostają zacofane, skorumpowane, dominują tam pionowe więzi społeczne. Do spopularyzowania kwestii dotyczącej roli kapitału społecznego w życiu publicznym przyczynił się R. D. Putnam, który podkreślił, iż: „Gospodarcze zacofanie istniejące na świecie może być w znacznej mierze wyjaśnione brakiem wzajemnego zaufania”. Zob. szerzej: R. D. Putnam, Demokracja $w$ działaniu. Tradycje obywatelskie we współczesnych Włoszech, Kraków 1995.

20 I. Słodkowska, Społeczeństwo obywatelskie na tle historycznego przełomu. Polska 1980-1989, Warszawa 2006, s. 45-46.

21 Jak podkreślił K. Dziubka: „Zarówno na gruncie doktrynalnym i filozoficznym, jak też w praktyce ustrojowej nie ukształtował się jeden określony model społeczeństwa obywatelskiego, którym można byłoby posługiwać się w analizach komparatystycznych bądź - jako wzorzec normatywny - w ocenie rozwoju politycznego, społecznego lub ekonomicznego różnych społeczeństw”. K. Dziubka, Społeczeństwo obywatelskie: wybrane..., op. cit., s. 34. 
W związku z tym, iż o społeczeństwie obywatelskim wspomina się zarówno w kontekście funkcjonowania państw demokratycznych, jak i autokratycznych proponuję przyjąć na potrzeby dalszych rozważań następującą typologię ${ }^{22}$ :

1) funkcjonalne społeczeństwo obywatelskie;

2) rewolucyjne społeczeństwo obywatelskie;

3) etyczne społeczeństwo obywatelskie.

System liberalno-demokratyczny stwarza najbardziej sprzyjające warunki do powstania i rozwoju społeczeństwa obywatelskiego; w tym wypadku pojawia się jego typ funkcjonalny. Charakteryzuje się on następującymi elementami ${ }^{23}$ :

1) praworządnością i pełną równością praw obywatelskich, politycznych i społecznych;

2) pluralizmem, to jest współistnieniem oraz wzajemnym poszanowaniem różnorodnych podmiotów, zorganizowanych na zasadzie dobrowolności oraz reprezentujących odmienne interesy;

3) istnieniem przestrzeni publicznej, w której - otwarcie i bez zagrożenia prześladowaniami politycznymi - mogą być artykułowane i dyskutowane różnorodne interesy społeczne.

Funkcjonalne społeczeństwo obywatelskie ogranicza omnipotencję państwa, niejednokrotnie uzupełnia jego działania, jak i - poprzez zaangażowanie obywateli - wzmacnia demokrację. A zatem stanowi mozaikę struktur użytecznych względem państwa demokratycznego, a także wobec interesów indywidualnych i grupowych.

Rewolucyjne społeczeństwo obywatelskie otwarcie występuje przeciwko niedemokratycznemu państwu i mobilizuje swe działania na rzecz zmian systemowych. Wysuwając postulaty zmian, rewolucyjne społeczeństwo staje przeciwko państwu w sytuacji zwarcia negocjacyjnego, stając się motorem przeprowadzenia i umocnienia zmian demokratycznych. Ten typ organizacji społeczeństwa wystapił np. w wielu państwach Ameryki Łacińskiej w drugiej połowie XX wieku, gdy zainicjowano przejście od systemów autokratycznych do demokratycznych. Natomiast etyczne społeczeństwo obywatelskie funkcjonuje poza państwem, a jego działalność często przyjmuje symboliczne formy protestu czy buntu ${ }^{24}$.

22 Opracowano na podstawie: I. Słodkowska, Społeczeństwo ..., op. cit., s. 49.

23 Ibidem, s. 73.

24 Zob. szerzej: ibidem, s. 51-54. 
Tak więc między państwem liberalno-demokratycznym a funkcjonalnym społeczeństwem obywatelskim zachodzi zależność o charakterze pozytywnym $^{25}$. W wypadku niedemokratycznego systemu politycznego między państwem a społeczeństwem obywatelskim zachodzi relacja negatywna $^{26}$. Mamy wówczas do czynienia z rewolucyjnym bądź etycznym społeczeństwem obywatelskim, przeciwstawiającym się oficjalnemu systemowi władzy ${ }^{27}$. W ten sposób społeczeństwo obywatelskie przygotowuje drogę przejścia od systemu autokratycznego do demokratycznego, co w dalszej perspektywie (po zmianie systemowej) umożliwia rozwój funkcjonalnego społeczeństwa obywatelskiego. Należy jednak pamiętać, iż mogą wystąpić trudności w tym zakresie.

Państwo o charakterze liberalno-demokratycznym tworzy otoczenie, w którym warunki sprzyjają powstaniu i prawidłowemu funkcjonowaniu społeczeństwa obywatelskiego. Pozostaje ono z państwem w określonych relacjach i zależnościach, na przykład poprzez wzajemne wspieranie właściwych obu stronom funkcji. Norberto Bobbio podkreślił, iż: „Społeczeństwo obywatelskie zajmuje przestrzeń zastrzeżoną dla formułowania postulatów (input), które są kierowane do systemu politycznego i na które system polityczny musi udzielić odpowiedzi (output) ${ }^{, 28}$. Z tego względu aktywność społeczeństwa obywatelskiego może przyjmować również formę kontroli lub modyfikacji działania instytucji państwa czy jego kształtu normatywnego.

Podstawowym warunkiem determinującym kształtowanie się funkcjonalnego społeczeństwa obywatelskiego jest spełnienie formalnych warunków i zasad ustroju demokratycznego. Społeczeństwo obywatelskie charakterystyczne jest dla państwa prawa, w którym stosunki między organami państwowymi oraz między organami a obywatelami i ich organizacjami określane są przez stabilne normy prawne ${ }^{29}$.

25 Zob. szerzej: E. Shils, Co to jest społeczeństwo obywatelskie?, w: Europa $i$ społeczeństwo obywatelskie. Rozmowy w Castel Gandolfo, przygotował i przedmową opatrzył K. Michalski, Kraków 1994, s. 20-22.

26 Należy dodać, iż możliwa jest również sytuacja, gdy w państwie niedemokratycznym w ogóle nie funkcjonuje społeczeństwo obywatelskie.

27 Zob. szerzej: I. Słodkowska, Społeczeństwo..., op. cit., s. 73-74.

28 N. Bobbio, Społeczeństwo obywatelskie, w: Ani ksiażę, Ani kupiec: Obywatel. Idea społeczeństwa obywatelskiego $w$ myśli współczesnej, wybór i wstęp J. Szacki, Kraków 1997, s. 66.

29 J. Wiśniewski, K. Żodź, Społeczeństwo..., op. cit., s. 46; zob. również: M. Magoska, O budowie społeczeństwa obywatelskiego w Polsce, w: Prawo w okresie przemian ustrojowych w Polsce, red. A. Wasilkowski, Warszawa 1995, s. 241-242. 
Istnienie demokracji proceduralnej jest warunkiem niezbędnym, ale niewystarczającym dla powstania dojrzałego społeczeństwa obywatelskiego. Oprócz formalnych zasad ustrojowych, stanowiących podstawę nowoczesnego społeczeństwa obywatelskiego istnieć musi wola i chęć uczestnictwa w życiu politycznym i społecznym ${ }^{30}$.

Jak wspomniano wcześniej, kategoria społeczeństwa obywatelskiego została wykorzystana w analizach dotyczących źródeł, przebiegu i charakteru rozpadu systemu ,realnego socjalizmu”. W analizach tych zwracano przede wszystkim uwagę na znaczenie powstania i rozwoju samodzielnych, niezależnych od państwa niedemokratycznego organizacji społecznych i zawodowych (Komitet Obrony Robotników i „Solidarność” w Polsce) oraz ich rolę w powstawaniu struktur organizacyjnych „społeczeństwa obywatelskiego", które pozostawały w opozycji (lub były alternatywa) wobec oficjalnych instytucji partii/państwa komunistycznego ${ }^{31}$.

Po upadku niedemokratycznych systemów politycznych w państwach Europy Środkowo-Wschodniej termin społeczeństwo obywatelskie traci swe bojowe konotacje charakterystyczne dla koncepcji Gramsciego ${ }^{32}$. $\mathrm{W}$ procesie przechodzenia do demokracji zadbano o taką reinterpretację terminu społeczeństwo obywatelskie, aby służył on liberalnej demokracji, a nie robotniczej rewolucji ${ }^{33}$. Jak podsumował B. Geremek, społeczeństwo obywatelskie „nie działa w opozycji do demokratycznego państwa, ale współpracuje z nim. Nie może to już być rodzaj paralelnej polis, teraz powinno być ono częścią polis" ${ }^{34}$.

Idea społeczeństwa obywatelskiego była głoszona w środowisku polskiej opozycji demokratycznej od 1976 roku. Widoczna była w przeciwstawianiu społeczeństwa i państwa, społeczeństwa i systemu politycznego oraz życia prywatnego i władzy publicznej. Idea ta na początku oznaczała potrzebę społecznej samoorganizacji w obliczu niedemokratycznej władzy, była obecna w programie „nowego ewolucjonizmu” Adama

30 J. Wiśniewski, K. Żodź, Społeczeństwo..., op. cit., s. 47.

31 K. Dziubka, Społeczeństwo obywatelskie, w: Leksykon politologii, red. A. Antoszewski, R. Herbut, Wrocław 2002, s. 416.

32 Na temat koncepcji Gramsciego zob. szerzej: B. Ponikowski, Dialektyka społeczeństwa obywatelskiego i społeczeństwa politycznego w myśli politycznej Antonia Gramsciego, w: Społeczeństwo obywatelskie, red. W. Bokajło, K. Dziubka, Wrocław 2001, s. 167-187.

33 E. Górski, Rozważania o społeczeństwie obywatelskim i inne studia z historii idei, Warszawa 2003, s. 49-50.

34 Ibidem, s. 80. 
Michnika $^{35}$ i ,samoograniczającej się rewolucji” Jacka Kuronia. Pojęcia te implikowały konieczność tworzenia „od dołu” autonomicznego społeczeństwa obywatelskiego ${ }^{36}$.

Model społeczeństwa obywatelskiego, funkcjonujący w ramach polskiej opozycji lat siedemdziesiątych i osiemdziesiątych XX wieku można określić mianem „etycznego"37. Współpraca opozycji z Kościołem katolickim wymuszała odwoływanie się do wartości etycznych, które w swej wymowie miały charakter uniwersalny, pozareligijny. W swych założeniach polska opozycja odrzucała przemoc i siłę jako formy walki z władzą. Konfrontacja miała odbywać się na gruncie wartości etycznych ${ }^{38}$. Szczególnie J. Kuroń był orędownikiem takich działań społecznych, które stworzyłyby szeroki margines swobody dla obywatelskiej inicjatywy z zachowaniem zasad etycznych. „Ludzie idei, którzy chcą zanegować istniejący system społeczny, muszą odwołać się do etyki jednostki ludzkiej, do jej niezbywalnych praw, z których jest przez system wywłaszczana. Ruch, który osobę ludzką i pełne możliwości jej rozwoju przyjmie za wartość nadrzędną, musi stworzyć utopię i zanegować istniejący porządek społeczny" 39 .

Przed powstaniem NSZZ „Solidarność” termin społeczeństwo obywatelskie pojawiał się rzadko i raczej przypadkowo, głównie w publicystyce emigracyjnej. Wraz z powstaniem Związku przywołany termin zaczął odgrywać coraz większą rolę $\mathrm{w}$ procesie gruntownych przemian ustrojo-

35 Strategia ewolucyjna dążyła do osiagnięcia zarówno krótko, jak i długoterminowych celów. Społeczeństwo i jego odnowę postrzegano na krótką metę jako cel sam w sobie. Z kolei w perspektywie długoterminowej w programie nowego ewolucjonizmu znalazły się cele wyraźnie polityczne, w dążeniu do których podstawowym środkiem miało być odnowione społeczeństwo. Zob. szerzej: J. Forbrig, Społeczeństwo obywatelskie $w$ dyskursie opozycji demokratycznej $w$ Europie Środkowej, w: Czas społeczeństwa obywatelskiego. Między teoriq a praktyka, red. B. Krauz-Mozer, P. Borowiec, Kraków 2006, s. 38-40.

36 Zob. szerzej: E. Górski, Rozważania..., op. cit., s. 58-59.

37 P. Ogrodziński, Pięć tekstów o społeczeństwie obywatelskim, Warszawa 1991, s. 70 .

38 Zob. szerzej: K. Rogaczewska, Recepcja myśli programowej Edwarda Abramowskiego w koncepcji społeczeństwa obywatelskiego Jacka Kuronia, w: Społeczeństwo obywatelskie, red. W. Bokajło, K. Dziubka, Wrocław 2001, s. 155-165; K. Rogaczewska, Koncepcja społeczeństwa obywatelskiego wedtug Jacka Kuronia, w: Czas społeczeństwa obywatelskiego. Między teoria a praktyka, red. B. Krauz-Mozer, P. Borowiec, Kraków 2006, s. 79-87.

39 J. Kuroń, Polityka i odpowiedzialność, Londyn 1984, s. 20. 
wych zachodzących w Polsce ${ }^{40}$. Od tego czasu występował w publicystyce opozycyjnej (gdzie skonstruowano model skrajnego dualizmu społeczeństwo obywatelskie-państwo komunistyczne), jak też w prasie oficjalnej ${ }^{41}$.

W latach 1987-1989 termin społeczeństwo obywatelskie pojawiał się w oficjalnej publicystyce wielu autorów o różnych orientacjach. Problematyka aktywizacji obywatelskiej i odbudowy społeczeństwa obywatelskiego poruszana była w zespole „Okragłego Stołu” do spraw reform politycznych, któremu przewodniczyli Janusz Reykowski i Bronisław Geremek $^{42}$.

Jest rzeczą ciekawą, że w tekstach przedstawicieli opozycji demokratycznej, a tym bardziej w przemówieniach ideologów późnego socjalizmu dość długo nie poruszano w ogóle problemów ekonomicznych wolnego rynku, własności prywatnej, prywatyzacji i reprywatyzacji gospodarki, podstaw materialnych społeczeństwa obywatelskiego, tak ważnych w kontekście anglosaskiej i liberalnej tradycji rozważań nad społeczeństwem obywatelskim. Społeczeństwo obywatelskie było początkowo rozumiane jako pojęcie z dziedziny moralności, pojęcie ułatwiające walkę z państwem komunistycznym o wolność, walkę bez potrzeby przeprowadzania gruntownej rewolucji w dziedzinie stosunków własnościowych. Społeczeństwo obywatelskie miało charakteryzować się jednością moralną jego obywateli, podobnie jak społeczeństwo socjalistyczne jednością moralno-polityczną jego członków ${ }^{43}$.

Dopiero w latach 1988-1989 nieco szerzej, choć nieśmiało zaczęto podnosić fundamentalny problem ,rozszerzania się społeczeństwa obywatelskiego na sferę ekonomiczną". Wraz z postępującą prywatyzacją gospodarki nastapił kryzys aktywności społecznej oraz pierwsze symptomy ucieczki od wolności, co było wynikiem zmęczenia społeczeństwa trudnościami gospodarczymi ${ }^{44}$.

40 Zob. szerzej: J. Szacki, Liberalizm..., op. cit., s. 112 i n.

41 Zob. szerzej: E. Górski, Rozważania..., op. cit., s. 62-63.

42 Zob. szerzej: ibidem, s. 71.

43 Ibidem, s. 74-75.

44 W latach dziewięćdziesiątych XX wieku, A. Siciński wyraził następujący pogląd: „W ostatnim dwudziestoleciu Polacy dwukrotnie podjęli próbę odbudowy społeczeństwa obywatelskiego. Po raz pierwszy w latach 1980-1981 na bazie NSZZ „Solidarność”; po raz drugi w latach 1989-1990 jako ruch komitetów obywatelskich. Pierwszą próbę zakończyło wprowadzenie stanu wojennego; drugą udaremniły elity polityczne". A. Siciński, Społeczeństwo obywatelskie, w: Władza i obywatel w społeczeństwie informacyjnym, red. M. Dietrich, Warszawa 1999, s. 17. 
W latach dziewięćdziesiątych XX wieku społeczeństwo polskie wydawało się być zagubione, okazywało oznaki wyuczonej bezradności, przejawiało skłonność do wycofania się z życia społeczno-politycznego zarówno w warunkach recesji, jak i ożywienia gospodarczego. W wyniku tego, społeczeństwo zaczęło doświadczać nowych form anomii, co w najogólniejszym rozumieniu oznacza sytuację, w której normy społeczne zostają pozbawione władzy regulowania ludzkich zachowań. Anomia to jednocześnie proces społeczny prowadzący do dosłownej demoralizacji - interakcje społeczne i społeczne więzi zaczynają nabierać cech cynizmu, koniunkturalizmu. Dzieje się tak między innymi ze względu na stale podtrzymywany w społeczeństwie konsumpcyjnym imperatyw zmuszający człowieka do osiaggnięcia określonego poziomu bezpieczeństwa egzystencjalnego, uzyskanego nawet kosztem zawieszenia lub złamania zbiorowych - w tym również prawnych - reguł i norm współżycia. Mając na uwadze normy prawne, anomią będziemy nazywać sytuację, w której obywatele traktują owe normy z osłabionym respektem lub wręcz przypisują im utratę mocy obowiązującej. Warto podkreślić, że anomia nie oznacza braku norm - obywatele znając je i rozumiejąc, przyjmują wobec nich postawę ambiwalentną. W efekcie, często spotykaną postawą społeczną jest permanentne lekceważenie prawa, nie wywołujące potępienia czy ostracyzmu ze strony innych obywateli ${ }^{45}$.

Według Piotra Glińskiego, głównymi przeszkodami w kształtowaniu się społeczeństwa obywatelskiego w Polsce są: brak pełnej akceptacji zasad wolnego rynku, instytucjonalne i świadomościowe pozostałości komunizmu, zbyt duże różnice w dochodach ludności, ostre konflikty społeczne ${ }^{46}$.

45 Zob. szerzej: K. Szafraniec, Anomia okresu transformacji a orientacje normatywne. Perspektywa międzygeneracyjna, w: Kondycja moralna spoleczeństwa polskiego, red. J. Mariański, Kraków 2002, s. 453; P. Sztompka, Socjologia. Analiza spoleczeństwa, Warszawa 2002, s. 275-276; L. Kolarska-Bobińska, Jakość polskiej demokracji, w: Polityka i świat wartości. Uczestnictwo obywateli w życiu spoteczno-politycznym, red. J. Miklaszewska, Kraków 1998; M. Torczyńska-Jarecka, Anomia czasów transformacji - refleksje w perspektywie deprywacji potrzeby bezpieczeństwa osobistego i prawnego, „Środkowoeuropejskie Studia Polityczne” 2005, $\mathrm{nr} 2$, s. $237-250$.

${ }^{46}$ Zob. szerzej: P. Gliński, O społeczeństwie obywatelskim w Polsce: teoria i praktyka, w: Homo eligens. Spoleczeństwo świadomego wyboru, red. D. Gawin, Warszawa 1999, s. 119-126; zob. również: T. Wallas, Sukcesy oraz zagrożenia transformacji systemu politycznego w Polsce na progu XXI wieku. Wybrane aspekty, w: Życie polityczne w Polsce. Wybrane problemy, red. T. Wallas, Poznań 2004, s. 46; K. A. Wojtaszczyk, Transformacja systemowa w Europie Wschodniej - próba bilansu, w: 
Wskazuje się również na fakt, iż nowa klasa polityczna jest postrzegana jako skłócona „klasa dla siebie”, zobojętniała na potrzeby zwykłych ludzi. Andrzej Celiński przyznał, że zamiast realizacji marzeń o zmitologizowanym społeczeństwie obywatelskim z czasów pierwszej „Solidarności” znaleźliśmy się w rzeczywistości „zatomizowanej społeczności, gdzie egoizm dominuje nad wspólnotowością" ${ }^{\text {"47 }}$. Należy również wskazać na słabość dyskusji ogólnonarodowej, która pozwoliłaby obywatelom zrozumieć dokonujące się przemiany ${ }^{48}$. Kolejna bardzo poważna bariera to, pochodzący z czasów komunizmu, a wciąż żywy i aktualny, podział społeczeństwa na „my” - zwykli obywatele i „oni” - władza. Istnieją także bariery związane z brakiem czasu, który jednostki mogłyby poświęcić działaniu społecznemu.

Niezwykle ważna jest także kondycja psychiczna obywateli, która wywiera wpływ zarówno na to, czy podejmują oni aktywność, jak również wpływa na rodzaj tejże aktywności. Zdaniem A. Wolff-Powęskiej, dokonujące się przemiany napotykają na opór jednostek „ukształtowanych w tradycji myślowej preferującej bierność, apatię, skłonność do myślenia roszczeniowego, nastawionych bardziej na liczenie na bezpieczeństwo gwarantowane z zewnątrz aniżeli na własne siły"49.

Według Piotra Borowca, można wyodrębnić trzy grupy przeszkód w procesie kształtowania się społeczeństwa obywatelskiego w Polsce ${ }^{50}$ :

1) przeszkody organizacyjno-prawne - okres potrzebny do ich usunięcia jest tożsamy z długością procesu legislacyjnego (przeszkody krótkoterminowe);

Transformacja systemowa w krajach Europy Środkowej i Wschodniej 1989-2002. Wybrane problemy, red. T. Godlewski, A. Koseski, K. A. Wojtaszczyk, Bydgoszcz-Pultusk 2003, s. 15-16.

47 A. Celiński, Wybraliśmy feudalizm, „Przegląd” 2003, nr 20, s. 37.

48 Jak podkreśliła J. Staniszkis, w okresie transformacji systemowej w Polsce ,pod pretekstem przeciwdziałania destabilizacji systemu politycznego unikano organizowania publicznych debat na temat kluczowych dla państwa i gospodarki decyzji"; J. Staniszkis, Dylematy okresu przejściowego - przypadek Polski, w: Społeczeństwo wobec wyzwań gospodarki rynkowej, red. W. Morawski, W. Kózek, Warszawa 1991, s. 37.

49 A. Wolff-Powęska, Oswojona rewolucja. Europa Środkowo-Wschodnia w procesie demokratyzacji, Poznań 1999, s. 160.

${ }^{50}$ Zob. szerzej: P. Borowiec, Główne przeszkody w realizacji idei spoleczeństwa obywatelskiego, w: Czas społeczeństwa obywatelskiego. Między teoriq a praktyka, red. B. Krauz-Mozer, P. Borowiec, Kraków 2006, s. 145-160. 
2) kwestie bytowe i oświata - ich usunięcie wymaga kilkunastu lub więcej lat;

3) niedostatek kapitału społecznego - czas potrzebny na usunięcie tej bariery to okres życia przynajmniej kilku pokoleń.

Jak podkreśliła Joanna Dzwończyk, pod względem kapitału społecznego społeczeństwo polskie wyraźnie odbiega in minus od pozostałych społeczeństw europejskich. Niepokojące jest zwłaszcza to, że mówić już można wręcz o utrwalonej tendencji braku zaufania, która dotyczy zarówno sfery prywatnej, jak i publicznej, na co składa się przekonanie o braku wpływu „zwykłych ludzi” na sprawy publiczne ${ }^{51}$. Warto w tym miejscu przytoczyć wyniki badania CBOS-u, które obrazują wskazane spostrzeżenie. Otóż w 2009 roku tylko co czwarty badany twierdził, że ma poczucie wpływu na sprawy państwa. W latach 90 . XX wieku sytuacja wyglądała jeszcze gorzej ${ }^{52}$. Nie ulega wątpliwości, iż w państwie demokratycznym zdecydowanie więcej obywateli powinno deklarować poczucie wpływu na sprawy wspólnoty politycznej.

Współczesne odrodzenie refleksji na temat społeczeństwa obywatelskiego jest próbą przeciwdziałania niedostatkom demokracji. Bezdyskusyjną kwestią dla wielu dzisiejszych badaczy pozostaje przekonanie głoszone od czasów Tocqueville'a, iż społeczeństwo obywatelskie jest naturalnym zapleczem dla demokracji. Demokracja bez społeczeństwa obywatelskiego nie funkcjonuje dobrze, gdyż dla prawidłowego działania tego systemu politycznego niezbędny jest kapitał społeczny, zaufanie, wola współpracy, znajomość spraw publicznych. Wymienione cechy są generowane właśnie przez społeczeństwo obywatelskie.

\section{Podsumowanie}

Odrodzenie społeczeństwa obywatelskiego w Polsce miało miejsce w okresie walki z państwem socjalistycznym. Analiza ówczesnej rzeczywistości społeczno-politycznej skłania do wniosku, iż w Polsce funkcjonowało etyczne społeczeństwo obywatelskie. Było ono istotnym elementem

51 Zob. szerzej: J. Dzwończyk, Rozwój społeczeństwa obywatelskiego w Polsce po 1989 roku, w: Czas społeczeństwa obywatelskiego. Między teoriq a praktyka, red. B. Krauz-Mozer, P. Borowiec, Kraków 2006, s. 169-172.

52 Zob. szerzej: Opinie o funkcjonowaniu demokracji $w$ Polsce, Komunikat z badań, Centrum Badania Opinii Społecznej, Warszawa 2009, s. 1-2. 
nacisku na niedemokratyczną władzę, która w ostateczności zgodziła się na rozmowy z przedstawicielami społeczeństwa. W efekcie wydarzeń 1989 roku został zapoczątkowany właściwy okres transformacji systemowej.

Po zmianie systemu politycznego negatywnie ukształtowana relacja na linii państwo-obywatele wywołuje pewne trudności. W związku z tym należy od nowa ukształtować wzajemne powiązania, gdyż system demokratyczny potrzebuje funkcjonalnego społeczeństwa obywatelskiego, które nie walczy z państwem, lecz z nim współpracuje. Ukształtowanie takiego typu organizacji społeczeństwa wymaga jednak czasu.

Po stworzeniu podstaw prawnych dla samoorganizacji niezbędne są zmiany w świadomości społecznej, które zaowocują wolą działania jednostek w celu kształtowania odzyskanej wolności. Jednakże za powodzenie procesu budowy funkcjonalnego społeczeństwa obywatelskiego odpowiedzialni są nie tylko obywatele. Warto także uzmysłowić rządzącym, iż powinni pomagać w powstaniu aktywnego, świadomego swoich praw społeczeństwa. W tym kontekście należy z ubolewaniem stwierdzić, że politycy nie zawsze kierują się tym wskazaniem. Warto chociażby spojrzeć na przepisy dotyczące inicjatywy ludowej na poziomie ogólnokrajowym, które zostały tak skonstruowane, aby ostateczną decyzję pozostawić $\mathrm{w}$ gestii przedstawicieli ${ }^{53}$. Korzystając $\mathrm{z}$ tego rozwiązania politycy wielokrotnie odrzucali wnioski obywateli, co powodowało przeświadczenie, że jakakolwiek aktywność nie ma sensu, gdyż i tak spotka się z brakiem zrozumienia i akceptacji. Jeśli chcemy, aby obywatele partycypowali w życiu społecznym musimy przyjąć takie regulacje, które zapewnią suwerenowi realny wpływ na otaczającą rzeczywistość. W przeciwnym wypadku, gdy obywatele będą mieli wrażenie, że chodzi tylko o piękne słowa, można być niemal pewnym, iż pozostaną biernymi obserwatorami.

\section{Bibliografia}

Antoszewski A., Spoleczeństwo obywatelskie a proces konsolidacji demokracji, w: Studia z teorii polityki, t. III, red. A. Czajowski, L. Sobkowiak, Wrocław 2000.

Blok Z., Transformacja jako konwersja funkcji wewnatrzsystemowych na przykładzie Polski, Poznań 2006.

53 Zob. szerzej: M. Rachwał, Inicjatywa ludowa a rozwój społeczeństwa obywatelskiego w Polsce w latach 1994-2005, w: Instytucje państwa a spoteczeństwo obywatelskie, red. A. Chodubski, L. Kacprzak, K. Pająk, Piła 2009, s. 231-246. 
Bobbio N., Społeczeństwo obywatelskie, w: Ani ksiażę, Ani kupiec: Obywatel. Idea społeczeństwa obywatelskiego w myśli współczesnej, wybór i wstęp J. Szacki, Kraków 1997.

Borowiec P., Główne przeszkody w realizacji idei społeczeństwa obywatelskiego, w: Czas społeczeństwa obywatelskiego. Między teoriq a praktykq, red. B. Krauz-Mozer, P. Borowiec, Kraków 2006.

Celiński A., Wybraliśmy feudalizm, „Przegląd” 2003, nr 20.

Opinie o funkcjonowaniu demokracji w Polsce, Komunikat z badań, Centrum Badania Opinii Społecznej, Warszawa 2009.

Dahrendorf R., Co zagraża społeczeństwu obywatelskiemu, w: Europa i społeczeństwo obywatelskie. Rozmowy w Castel Gandolfo, przygotował i przedmową opatrzył K. Michalski, Kraków 1994.

Dziubka K., Społeczeństwo obywatelskie, w: Leksykon politologii, red. A. Antoszewski, R. Herbut, Wrocław 2002.

Dziubka K., Społeczeństwo obywatelskie: wybrane aspekty ewolucji pojęcia, w: Studia z teorii polityki, t. II, red. A. W. Jabłoński, L. Sobkowiak, Wrocław 1998.

Dzwończyk J., Determinanty rozwoju społeczeństwa obywatelskiego w Polsce po 1989 roku, w: Rola wyborów w procesie ksztattowania się społeczeństwa obywatelskiego w Polsce, red. S. Drobczyński, M. Żyromski, Poznań 2004.

Dzwończyk J., Rozwój społeczeństwa obywatelskiego w Polsce po 1989 roku, w: Czas społeczeństwa obywatelskiego. Między teoriq a praktykq, red. B. Krauz-Mozer, P. Borowiec, Kraków 2006.

Forbrig J., Społeczeństwo obywatelskie w dyskursie opozycji demokratycznej w Europie Środkowej, w: Czas społeczeństwa obywatelskiego. Między teoria a praktyka, red. B. Krauz-Mozer, P. Borowiec, Kraków 2006.

Gliński P., O społeczeństwie obywatelskim w Polsce: teoria i praktyka, w: Homo eligens. Społeczeństwo świadomego wyboru, red. D. Gawin, Warszawa 1999.

Górski E., Rozważania o społeczeństwie obywatelskim i inne studia z historii idei, Warszawa 2003.

Kolarska-Bobińska L., Jakość polskiej demokracji, w: Polityka i świat wartości. Uczestnictwo obywateli w życiu społeczno-politycznym, red. J. Miklaszewska, Kraków 1998.

Koselleck R., Trzy światy obywatelskie? Wprowadzenie do porównawczej semantyki społeczeństwa obywatelskiego w Niemczech, Anglii i Francji-zarys dziejów teorii, w: Europa i spoteczeństwo obywatelskie. Rozmowy w Castel Gandolfo, przygotował i przedmową opatrzył K. Michalski, Kraków 1994.

Kumar K., Społeczeństwo obywatelskie: rozważania na temat użyteczności historycznego terminu, w: Ani ksiażę, Ani kupiec: Obywatel. Idea społeczeństwa obywatelskiego w myśli współczesnej, wybór i wstęp J. Szacki, Kraków 1997.

Kuroń J., Polityka i odpowiedzialność, Londyn 1984. 
Magoska M., O budowie społeczeństwa obywatelskiego w Polsce, w: Prawo w okresie przemian ustrojowych w Polsce, red. A. Wasilkowski, Warszawa 1995.

Michalski K., Przedmowa, w: Europa i społeczeństwo obywatelskie. Rozmowy w Castel Gandolfo, przygotował i przedmową opatrzył K. Michalski, Kraków 1994.

Ogrodziński P., Pięć tekstów o społeczeństwie obywatelskim, Warszawa 1991.

Paradowska W., O podmiocie etycznym i podmiocie etyki, w: Unia Europejska a spoteczeństwo obywatelskie, red. R. Paradowski, Poznań 2005.

Perez-Diaz V. M., Powrót społeczeństwa obywatelskiego w Hiszpanii, Kraków 1996.

Pietrzyk-Reeves D., Idea społeczeństwa obywatelskiego. Współczesna debata i jej źródta, Wrocław 2004.

Ponikowski B., Dialektyka społeczeństwa obywatelskiego i społeczeństwa politycznego w myśli politycznej Antonia Gramsciego, w: Społeczeństwo obywatelskie, red. W. Bokajło, K. Dziubka, Wrocław 2001.

Putnam R. D., Demokracja w działaniu. Tradycje obywatelskie we współczesnych Włoszech, Kraków 1995.

Rachwał M., Inicjatywa ludowa a rozwój społeczeństwa obywatelskiego $w$ Polsce w latach 1994-2005, w: Instytucje państwa a społeczeństwo obywatelskie, red. A. Chodubski, L. Kacprzak, K. Pająk, Piła 2009.

Rogaczewska K., Koncepcja społeczeństwa obywatelskiego wedtug Jacka Kuronia, w: Czas społeczeństwa obywatelskiego. Między teoria a praktyka, red. B. Krauz-Mozer, P. Borowiec, Kraków 2006.

Rogaczewska K., Recepcja myśli programowej Edwarda Abramowskiego w koncepcji społeczeństwa obywatelskiego Jacka Kuronia, w: Społeczeństwo obywatelskie, red. W. Bokajło, K. Dziubka, Wrocław 2001.

Shils E., Co to jest społeczeństwo obywatelskie?, w: Europa i społeczeństwo obywatelskie. Rozmowy w Castel Gandolfo, przygotował i przedmową opatrzył K. Michalski, Kraków 1994.

Siciński A., Społeczeństwo obywatelskie, w: Władza i obywatel w społeczeństwie informacyjnym, red. M. Dietrich, Warszawa 1999.

Słodkowska I., Społeczeństwo obywatelskie na tle historycznego przełomu. Polska 1980-1989, Warszawa 2006.

Staniszkis J., Dylematy okresu przejściowego - przypadek Polski, w: Społeczeństwo wobec wyzwań gospodarki rynkowej, red. W. Morawski, W. Kózek, Warszawa 1991.

Szacki J., Liberalizm po komunizmie, Kraków 1994.

Szafraniec K., Anomia okresu transformacji a orientacje normatywne. Perspektywa międzygeneracyjna, w: Kondycja moralna społeczeństwa polskiego, red. J. Mariański, Kraków 2002.

Sztompka P., Socjologia. Analiza spoteczeństwa, Warszawa 2002.

Taylor Ch., Kiedy mówimy: społeczeństwo obywatelskie, w: Europa i społeczeństwo obywatelskie. Rozmowy w Castel Gandolfo, przygotował i przedmową opatrzył K. Michalski, Kraków 1994. 
Torczyńska-Jarecka M., Anomia czasów transformacji - refleksje w perspektywie deprywacji potrzeby bezpieczeństwa osobistego i prawnego, „Środkowoeuropejskie Studia Polityczne" 2005, nr 2.

Wallas T., Sukcesy oraz zagrożenia transformacji systemu politycznego w Polsce na progu XXI wieku. Wybrane aspekty, w: Życie polityczne w Polsce. Wybrane problemy, red. T. Wallas, Poznań 2004.

Weigel G., Ostateczna rewolucja: Kościót sprzeciwu a upadek komunizmu, Poznań 1995.

Wiśniewski J., Żodź K., Spoleczeństwo obywatelskie a społeczeństwo Unii Europejskiej, w: Unia Europejska a społeczeństwo obywatelskie, red. R. Paradowski, Poznań 2005.

Wojtaszczyk K. A., Transformacja systemowa w Europie Wschodniej-próba bilansu, w: Transformacja systemowa $w$ krajach Europy Środkowej $i$ Wschodniej 1989-2002. Wybrane problemy, red. T. Godlewski, A. Koseski, K. A. Wojtaszczyk, Bydgoszcz-Pułtusk 2003.

Wolff-Powęska A., Oswojona rewolucja. Europa Środkowo-Wschodnia w procesie demokratyzacji, Poznań 1999.

\section{Summary}

In order to function properly, a modern democracy needs a civic society, that is a society of individual, conscious subjects, who are active in the public realm. The absence of this component of democracy results in numerous problems, if only to mention low turnout in elections and referenda, thereby weakening the legitimacy of power and difficulties in the implementation of political decisions.

Many authors emphasize the fact that the 1980 s were a period of very intensive development in civic society in Poland which persuaded the authorities at the time to commence talks with the democratic opposition. The outcome of the talks of the Round Table, the elections in June 1991 and further events, was that a democratic political system was institutionalized in Poland. After several years of political transformation the issue of the weakness of Polish civic society was raised more and more frequently. Therefore, the question may be asked of what has happened to Polish society? A society that was once able to force the non-democratic authorities to make concessions after the turning point of 1989, has become less and less involved in public life.

In trying to address this problem one needs to emphasize the fact that Polish civic society was revived at the time of the struggle against the socialist state. After the change of political system, the negative aftermath of the relations between state and citizens has produced certain difficulties. Consequently, new mutual relations need to be established between state and citizens, since a democratic system requires a functioning civic society that does not struggle against the state but rather collaborates with it. It takes time to develop such an organization of society, though. 